\title{
Developing of transgenic wheat cultivars for improved disease resistance
}

\author{
A. H. Fahmy ${ }^{1}$, R. A. Hassanein ${ }^{2}$, H. A. Hashem ${ }^{2 *}$, A. S. Ibrahim³ ${ }^{3}$ O. M. El Shihy ${ }^{3}$, E. A. Qaid ${ }^{4}$ \\ ${ }^{1}$ Department of Plant Genetic Transformation, Agricultural Genetic Engineering Research Institute, 9 Gamaa St. Giza, Egypt, ${ }^{2}$ Department of Botany, Faculty \\ of Science, Ain Shams University, Abbassia, Cairo, Egypt, ${ }^{3}$ Department of Plant Physiology, Faculty of Agriculture, Cairo University, Egypt, ${ }^{4}$ Department of \\ Biology, Faculty of Science, Taiz University, Yemen
}

\begin{tabular}{|c|c|}
\hline ARTICLE INFO & ABSTRACT \\
\hline $\begin{array}{l}\text { Article history: } \\
\text { Received on: October } 11,2017 \\
\text { Accepted on: December } 14,2017 \\
\text { Available online: February } 17,2018\end{array}$ & $\begin{array}{l}\text { Wheat (Triticum aestivum L.) and (Triticum turgidum L.) are largely cultivated in the world. They are economically } \\
\text { important because they can be grown in a wide range of climates and geographic regions. Wheat plants are exposed } \\
\text { to a wide variety of disease pathogens, i.e., fungal, bacterial, and viral pathogens. The present work is an attempt } \\
\text { to develop disease-resistant wheat cultivars. In this respect, immature embryo-derived calli of } 2 \text { wheat cultivars; }\end{array}$ \\
\hline $\begin{array}{l}\text { Key words: } \\
\text { Rice chitinase, } \\
\text { Immature embryo, } \\
\text { Transformation, } \\
\text { Triticum aestivum, } \\
\text { Triticum durum }\end{array}$ & $\begin{array}{l}\text { Sids } 1 \text { (bread wheat) and Bani Suef } 6 \text { (durum wheat) were transformed by rice chitinase (cht 2), gus reporter gene, } \\
\text { and selectable marker (bar) genes using particle bombardment technique. Transient gus expression in calli and } \\
\text { stable gus expression in transformed nodes were observed. Transgenic calli were selected on phosphinothricin } \\
\text { containing regeneration medium, and putative transformants were grown to maturity. } 40 \text { herbicide-resistant putative } \\
\text { transformants were selected after leaf painting with } 0.2 \% \text { liberty herbicide. Presence and integration of transgenes } \\
\text { were assessed by subjecting transgenic plants to polymerase chain reaction analysis using specific primers for } \\
\text { gus, bar, and cht } 2 \text { genes. Transformation frequencies for cht } 2 \text { were } 3.96 \% \text { and } 3.02 \% \text { in Sids } 1 \text { and Bani Suef } 6 \text {, } \\
\text { respectively. The incorporation of rice chitinase gene in transformants was confirmed by Dot blot analyses. }\end{array}$ \\
\hline
\end{tabular}

\section{INTRODUCTION}

Wheat (Triticum aestivum L.) is the first important and strategic cereal grain crop for the majority of world's populations. Its share of $15 \%$ proves importance of wheat production in the world economy from 1500 million hectares arable land in the world. This rate is equivalent to 225 million hectares of wheat area based on FAO figures for 2009. Wheat is an important cereal crops and an essential ingredient of the human diet indisputably in the most worldwide. Wheat provides nearly $55 \%$ of the carbohydrates and $20 \%$ of the food calories consumed globally [1]. It exceeds in acreage and production every other grain crop (including rice, maize, etc.).

Wheat plants are exposed to a wide variety of disease pathogens, i.e., fungal, bacterial, and viral pathogens. In nature, spikes, leaves, and roots of wheat plants can be infected, and that led to substantial yield loss. Chemical application is not economical and is also detrimental to the environment. Developing of genetically resistance wheat

*Corresponding Author

H. A. Hashem,

Department of Botany,

Faculty of Science, Ain Shams University,

Abbassia, Cairo, Postcode: 11566, Egypt.

ORCID 0000-0001-7210-3226.

E-mail: Hashem.hanan@gmail.com varieties is the most economical and efficient way to protect wheat from pathogens [2]. Chitinases (EC 3.2.1.14) catalyze the hydrolytic cleavage of the $\beta$-1,4-glycosidic bonds between biopolymers N-acetylglucosamine residues from the chitin molecule [3-6]. Chitinase proteins are known as pathogenesis-related proteins that are strongly induced when host plant cells are challenged by pathogen stress, and thus chitinases constitute an important arsenal of plants against fungal pathogens. There are some reports that chitinase activity in transgenic plants increased the inhibition of fungal growth, improving resistance against fungal attack and increase resistance to a wide range of disease pathogens [7-11].

The objective of the present study was to improve disease resistance of wheat cultivars (T. aestivum L.cv. Sids 1) and (T. turgidum ssp. Durum $\mathrm{cv}$. Bani Suef 6) by introducing rice chitinase gene $c h t 2$ which confers a wide range of disease resistance.

\section{MATERIALS AND METHODS}

\subsection{Plant Material and Tissue Culture}

Immature caryopsis of the two Egyptian wheat cultivars Sids 1 and Bani Suef 6 was collected approximately 2 weeks post-anthesis. Immature seeds were surface sterilized by soaking for $1 \mathrm{~min}$ in $70 \%$ (v/v) ethanol followed by $20 \%$ commercial Clorox $(5.25 \%$ sodium hypochlorite) supplemented with few drops of Tween 20 and washed 
5 times with sterile ddH $\mathrm{H}_{2} \mathrm{O}$. Immature embryos for each cultivar, scutella $1-1.25 \mathrm{~mm}$ in diameter, were aseptically isolated and cultured scutellum side up on callus induction medium modified for wheat cell culture [12]. Basically, it contains Murashige and Skoog (MS) salt [13], supplemented with $2 \mathrm{mg} / 1$ 2,4-dichlorophenoxyacetic acid $(2,4-\mathrm{D})$ as a source of auxin, $150 \mathrm{mg} / \mathrm{L}$ of L-Asparagine, $100 \mathrm{mg} / \mathrm{L}$ of myo-inositol, $20 \mathrm{~g} / \mathrm{L}$ sucrose and adjusted to $5.8 \mathrm{pH}$ with $1 \mathrm{M} \mathrm{KOH}$ solution and solidified by $2.5 \mathrm{~g} / \mathrm{L}$ phytagel [14]. Immature embryos were maintained in the dark at $25^{\circ} \mathrm{C}$ for 1 week.

\subsection{DNA Constructs}

Two different plasmids were used for cobombardment experiments: PAHCht-2 (kindly provided by Prof. Dr. S. Muthukishnan; Department of Biochemistry, Kansas State University, Kansas, USA) contains the Cht-2 gene, which is a $1.1 \mathrm{~Kb}$ rice chitinase Class I under the transcriptional control of the maize ubiquitin promoter [Figure 1a] and pAB6 [Figure 1b] contains gus $(1.8 \mathrm{~Kb})$ gene(driven by rice Act1 intron promoter and the nopaline synthase nos terminator and the selectable marker/herbicide resistance bar $(0.6 \mathrm{~Kb}$ phosphinothricin acetyl transferase) gene (driven by cauliflower mosaic virus $35 \mathrm{~S}$ promoter and the nopaline synthase nos terminator) [15].

\subsection{Bacterial Strain}

The highly efficient competent cells of Escherichia coli (DH10ß) were used for the transformation with the plasmids DNA and prepared according to the method of Ausubel et al. [16].

\subsection{Plasmid Transformation into $E$. coli Competent Cells}

Calcium chloride treatment of E. coli (DH10 $\beta$ ) produces competent cells that will transform by the pAB6 plasmid or pACHt-2 plasmid using heat shock step according to Tu et al. [17].

\subsection{Plasmid Purification}

Bacteria harboring the pAB6 plasmid or pAHCht-2 plasmid were grown in liquid Luria broth medium $(\mathrm{pH} 7.4)$ at $37^{\circ} \mathrm{C}$ in a growth shaker incubator. Megaprep purification of DNA plasmid was done using Wizard ${ }^{\mathrm{TM}}$ Megapreps DNA Purification System (Promega, USA).

\subsection{Preparation and Coating of Gold Particles with Plasmid DNA}

Microcarriers ( $1 \mu \mathrm{m}$ gold particles) were prepared and coated with plasmid DNA according to the protocol by Sanford et al. [18].

\subsection{Wheat Transformation}

The transformation procedure was performed as modified by Fahmy et al. [12]. A 1:1 ratio of pAB6 and pAHCht-2 were cotransformed into Sids1 and Bani Suef 6 calli. Plant transformation was carried out by particle bombardment using the Biolistic ${ }^{\circledR}$ PDS-1000/He particle gun device (Bio-Rad, USA). 1-week-old calli were transferred to a modified callus induction medium (supplemented with $0.2 \mathrm{M}$ mannitol and $0.2 \mathrm{M}$ sorbitol) for 4 hours followed by bombardment with $0.6 \mu$ gold particles coated with plasmid DNA. The distance between the particle holder and target was $6 \mathrm{~cm}$, and helium pressure was $1100 \mathrm{psi}$. Calli were remained for additional $16 \mathrm{~h}$ on the same osmotic treatment and then transferred to recovery medium for 5 days. Calli were then assayed by histochemical GUS activity assay. The remaining calli were transferred to selective medium supplemented with $3 \mathrm{mg} / \mathrm{L}$ PPT. After 4 weeks the survived embryogenic calli were placed on regeneration medium supplemented with $1 \mathrm{mg} / \mathrm{L}$ PPT and $1.5 \mathrm{mg} / \mathrm{L}$ thidiazuron (TDZ) for 4 weeks under light $\left(16 \mathrm{~h}\right.$ ) and temperature $25^{\circ} \mathrm{C}$ and finally the green shoots were placed on rooting medium (half strength MS medium).

\subsection{Acclimatization}

After development of a root system, regenerated putatively transgenic plants were then transferred to soil mixture; peat moss:sand:clay with a ratio (1:1:1); respectively, in small pots and covered with plastic pages, and then placed in a controlled growth chamber at $25^{\circ} \mathrm{C}$ for 3 weeks, they were transferred to big pots and grown to maturity under greenhouse conditions.

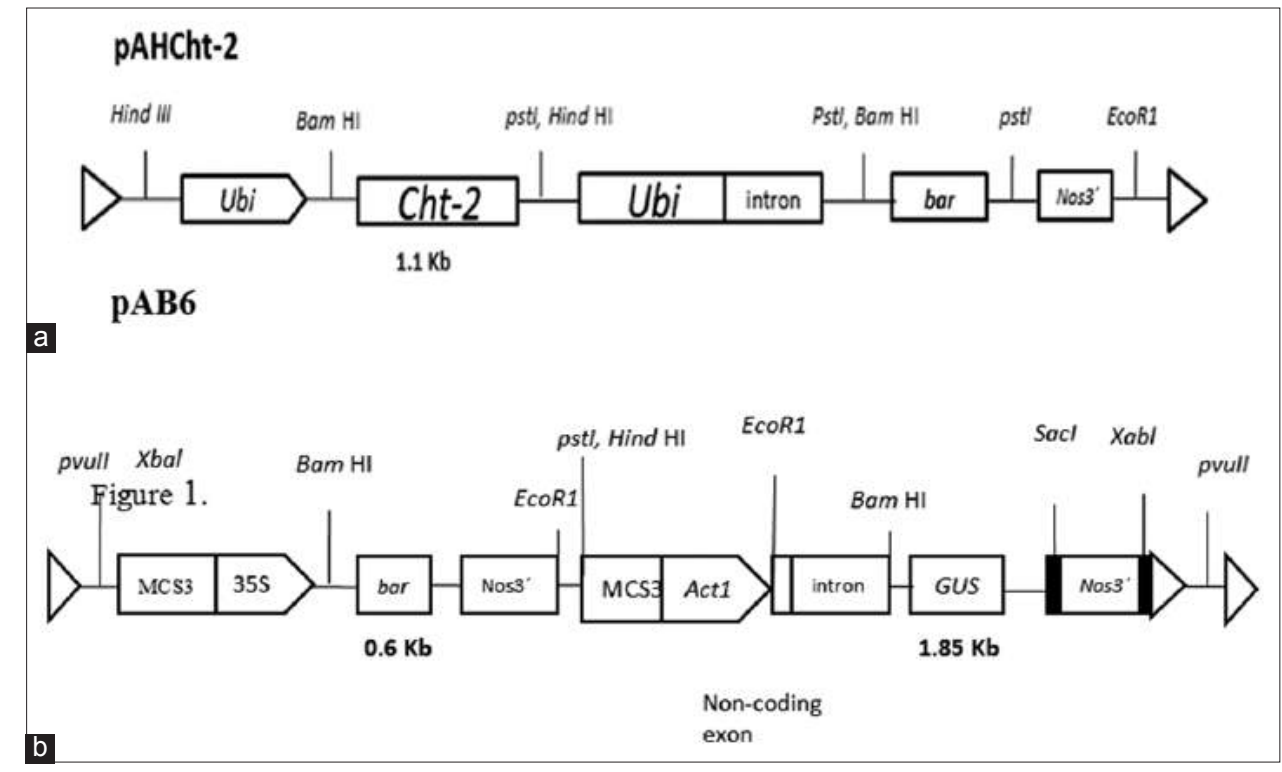

Figure 1: Schematic representation of plasmids pAHCht-2 (a) and pAB6 (b) used for cobombardment. 


\subsection{Assay of $\beta$-glucuronidase (gus) Activity}

GUS assay was carried out as described by Jefferson et al. [19]. Calli were incubated in X-Glue solution containing $1 \mathrm{mM}$ (5-bromo-4chloro-3-indolyl- $\beta$-D-glucuronide), $0.1 \%$ (v/v) Triton X-100, 20\% methanol and $100 \mathrm{mM}$ sodium phosphate buffer $(\mathrm{pH} 7.0)$, and 0.5 $\mathrm{mM}$ potassium ferricyanide. To compare transient and stable gus transformation, GUS analysis was done.

\subsection{Transient gus Expression}

For observing transient gus expression, bombardment calli after 2 days on induction medium were dipped in GUS staining solution and were incubated at $37^{\circ} \mathrm{C}$ for $2-3$ days and then callus expressing gus photographed under the binocular stereomicroscope.

\subsection{Stable gus Expression}

For observing stable gus expression, regenerated plants were assayed by dipping transformed plantlets into GUS staining solution. The reaction mixture was incubated at $37^{\circ} \mathrm{C}$ for $2-3$ days, chlorophyll was extracted from the tissue by incubation in $70 \%$ ethanol followed by $100 \%$ ethanol and regenerated plants expressing gus were photographed under the binocular stereomicroscope.

\subsection{Assay of bar Expression Analysis}

Leaf painting assay was used to study the integration and expression of the bar gene in T0 plants according to Cho et al. [20]. Liberty solution $(0.2 \%)$, containing $0.1 \%(\mathrm{v} / \mathrm{v})$ Tween-20, was applied to leaf sections using a cotton swab. Resistance to the herbicide solution was examined after 7 days of application by observing leaf necrosis.

\subsection{Polymerase chain reaction (PCR) analysis}

Total genomic DNA was isolated from wheat leaves using a cetyltrimethylammonium bromide extraction method [21]. The PCR analysis was used to confirm the presence or the absence of the three transgenes (cht 2, bar, and gus) in the transformed plants. The specific primers used to amplify of cht 2 gene were 5'TAAGGATGTCGACGCCGAGAGGGG3' and 5'CGTCAGTCCTCATCACTGCTCCGG3'. The forward and reverse primers employed for detection of bar gene were 5'CAG ATC TCG GTG ACG GGC AGG C3`and 5 `CCG TAC CGA GCC GCA GGA AC -3`; and for gus gene were 5 `AGT GTA CGT ATC ACC GTT TGT GTG AAC 3`and 5'AGT GTA CGT ATC ACC GT TTG TGT GAA C3 $3^{\prime}$. The PCR program profile for three genes was done as follow: Initial denaturation at $94^{\circ} \mathrm{C}$ for $5 \mathrm{~min}$, followed by 35 cycles at $94^{\circ} \mathrm{C}$ for $30 \mathrm{sec}$, annealing for $30 \mathrm{sec}$ and $72^{\circ} \mathrm{C}$ for $1 \mathrm{~min}$ and finally, an additional elongation step was performed for $5 \mathrm{~min}$ at $72^{\circ} \mathrm{C}$. The annealing temperature for the amplification of cht 2, bar, and gus genes was $61.3^{\circ} \mathrm{C}, 58^{\circ} \mathrm{C}$, and $62^{\circ} \mathrm{C}$, respectively. The PCR reaction mixture contained $50 \mathrm{ng}$ of template DNA, $0.5 \mu \mathrm{M}$ of each primer, $10 \mathrm{mM}$ of deoxynucleotides, $2.5 \mathrm{mM}$ of $\mathrm{MgCl}_{2}$, PCR buffer, and Taq polymerase in a volume of $25 \mu 1$. The amplified products were electrophoretically resolved on a $1 \%$ agarose gel in Tris-acetate EDTA buffer.

\subsection{Dot Blot Hybridization Analysis}

Dot blot analysis was performed to confirm stable integration of the cht-2 gene. Total genomic DNA was isolated from wheat leaves of putative transgenic of both cultivars that showed the presence of $1.1 \mathrm{~Kb}$ chitinase amplification products in PCR analysis and from nontransgenic plants (negative control) and pAHCht-2 (positive control), they were denatured and neutralized with $0.4 \mathrm{M} \mathrm{NaOH}, 10 \mathrm{mM}$ EDTA, incubated at $96^{\circ} \mathrm{C}$ for $10 \mathrm{~min}$, then rapidly cooled in ice. Using a dot blot manifold, samples were spotted onto pre-soaked nitrocellulose membrane cover two pieces of Whatman paper. Membrane was crosslinked under UV light. Hybridization was performed at $45^{\circ} \mathrm{C}$ for overnight in a buffer containing $5 \times$ Denhardt's solution, $6 \times$ sodium chloride-sodium citrate (SSC), $0.5 \%$ sodium dodecyl sulfate (SDS), and $50 \%(\mathrm{v} / \mathrm{v})$ deionized formamide and followed by the addition of pAHCht-2 as a probe. Membrane was washed twice at room temperature in $2 \times \mathrm{SSC} / 0.1 \% \mathrm{SDS}$ for $5 \mathrm{~min}$ followed by two washes in $0.1 \times \mathrm{SSC} / 0.1 \% \mathrm{SDS}$ for $20 \mathrm{~min}$ at $70^{\circ} \mathrm{C}$. Direct procedure and detection system were carried out by Biotin Chromogenic Detection Kit (Thermo Scientific). Blot was washed and product detection conducted by the addition of 5-bromo-4-chloro-3'-indolyphosphate p-toluidine salt/nitro-blue tetrazolium chloride solution, then the blot was exposed to photography.

\section{RESULTS}

In the present study, the particle bombardment approach was used in the wheat transformation to produce transgenic plants, harboring cht 2 and bar genes to enhance disease resistance against fungal diseases and herbicides.

\subsection{Callus Induction and Bombardment}

Immature embryos of bread wheat cultivar (Sids 1) and durum wheat cultivar (Bani Suef 6) were used as explants for wheat transformation [Figures 2a and 3a]. In total, 500 immature embryos from each cultivar were cultured on callus induction medium [Tables 1 and 2]. Immature embryos from the two cultivars were cultured on callus induction medium containing $2 \mathrm{mg} / \mathrm{L}$ auxin $(2,4-\mathrm{D})$ and incubated at $25^{\circ} \mathrm{C}$ in the dark for one week. Callus initiation was observed after $72 \mathrm{~h}$ for both wheat cultivars. After 1 week from incubation, cultured immature embryos from wheat cultivars were induced and formed callus as shown in Figures $2 \mathrm{~b}$ and $3 \mathrm{~b}$. Callus induction rate (\%) was calculated as number of explants forming callus/cultured immature embryos $\times 100$. The callus induction rate was higher in case of bread wheat cultivar Sids $1(75.6 \%)$ compared to $72.8 \%$ callus induction rate in durum wheat cultivar Bani Suef 6.

Immature embryo-derived calli from both wheat cultivars were transferred and arranged in the center of a Petri dish containing osmotic medium and then cotransformed with gold particles coated with pAHCht-2 and pAB6 plasmids. Bombarded calli from both wheat cultivars were remained on osmotic medium for $16 \mathrm{~h}$ and then transferred into induction medium (recovery) for 5 days as shown in Figures $2 \mathrm{~d}$ and $3 \mathrm{~d}$.

\subsection{Callus Selection}

After 5 days from bombardment, bombarded calli from both wheat cultivars were transferred to selection medium supplemented with 3 $\mathrm{mg} / \mathrm{L}$ PPT. The number of survived calli after the first selection phase for resistant calli, which showed active proliferation, was 262 for cv. Sids 1 and 181 for cv. Bani Suef 6 that represented $69.3 \%$ and $49.7 \%$ from bombarded immature embryos derived calli [Tables 1 and 2]. All survived calli from both cultivars were placed onto selection medium for 2 weeks for the second round of selection. Results from Tables 1 and 2 showed that after second selection phase $30.1 \%$ and $28.0 \%$ from bombarded calli were survived for $\mathrm{cv}$. Sids 1 and cv. Bani Suef 6 , respectively. 

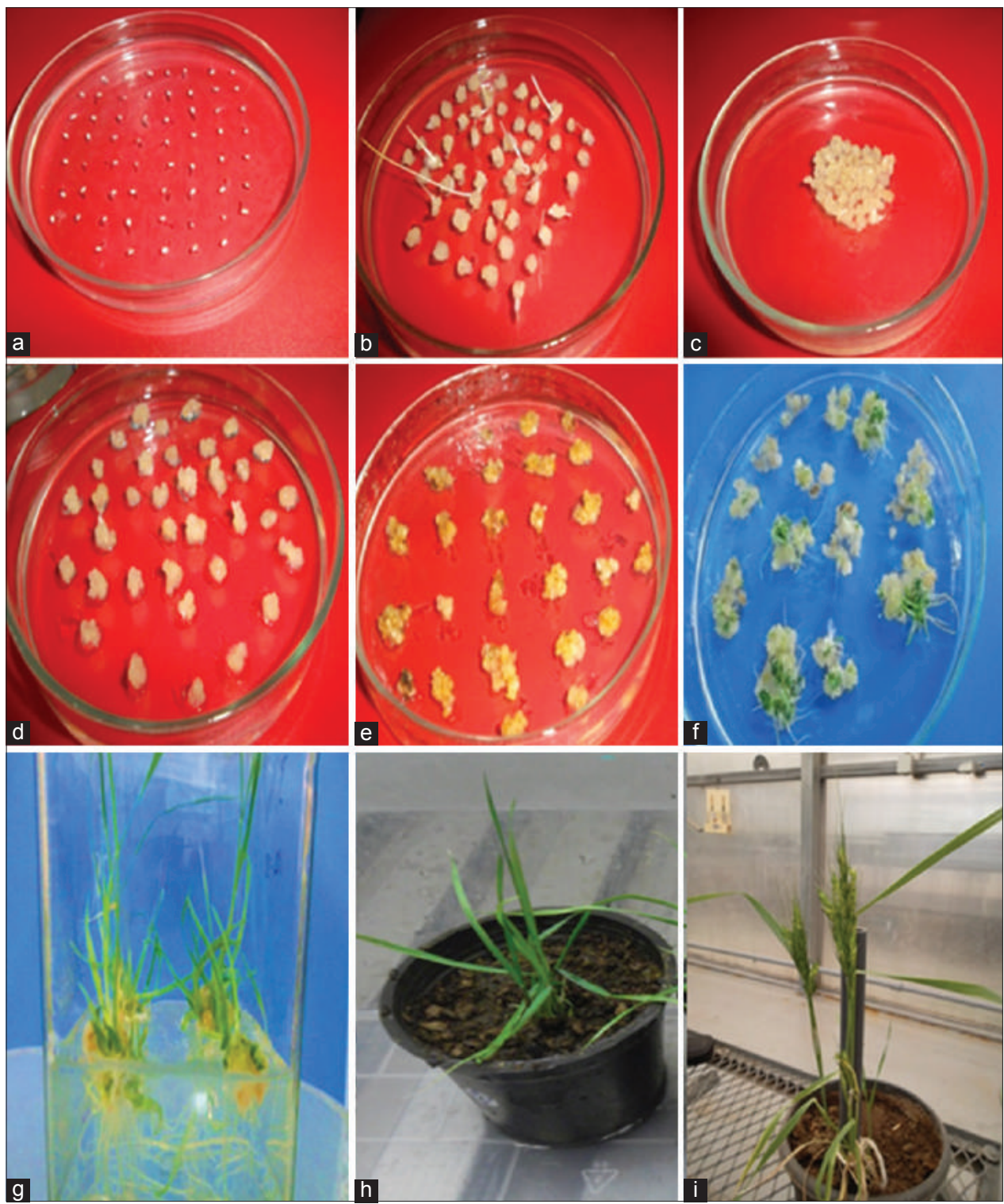

Figure 2: Production stages of transgenic bread wheat cultivar Sids 1 with pAHcht-2 and pAB6 plasmids by particle bombardment. (a) Immature embryos cultured on callus induction medium. (b) Induced calli on callus induction medium. (c) Induced calli on osmotic medium. (d) Bombarded calli on callus induction recovery medium. (e) Calli on selection medium containing $3 \mathrm{mg} / \mathrm{L}$ phosphinothricin. (f) Regeneration of putative transgenic plantlets. (g) Plantlets on rooting medium. (h and i): Acclimation of putative transformed plants.

\subsection{Regeneration of Transgenic Wheat Plants}

Survived calli from the two wheat cultivars were transferred onto regeneration medium containing $1.5 \mathrm{mg} / \mathrm{L}$ TDZ plus $1 \mathrm{mg} / \mathrm{L}$ PPT. After 4 weeks, the percentage of regeneration was calculated as number of callus lines with green plantlets/number of calli transferred for regeneration $\times 100$. The percentage of regeneration was $63.15 \%$ for Sids 1 and $51.96 \%$ for Bani Suef 6 [Tables 1 and 2, Figures $2 \mathrm{f}$ and $3 \mathrm{f}]$.

The regenerated plantlets from three wheat cultivars were transferred to rooting medium [Figures $2 \mathrm{~g}$ and $3 \mathrm{~g}$ ], and healthy plantlets were transferred to small pots and kept in growth chamber [Figures $2 \mathrm{~h}$ and $3 \mathrm{~h}$, then transferred to big pots and placed on the greenhouse for acclimation [Figures $2 \mathrm{i}$ and 3i]. Results from Tables 1 and 2 showed that the transformation efficiency was $5.29 \%$ for cv. Sids 1 and $4.67 \%$ for cv. Bani Suef 6 .

\subsection{GUS Expression Analysis}

Results from Figures 4a and c showed that the non-transformed calli for each wheat cultivars did not change in color, whereas transformed calli exhibited the characteristic blue color that indicates integration and expression of gus gene [Figure $4 \mathrm{~b}$ and $\mathrm{d}$ ].

\subsection{Bar Expression Analysis}

All acclimatized plants in both bread wheat cultivar (Sids 1) and durum wheat (cv. Bani Suef 6) showed a high level of resistance to the herbicide most likely because they carried two copies of the bar gene, one from each transformation plasmid. Non-transgenic plants showed yellowing in the applied area after 3 days from Liberty application in both wheat cultivars [Figure 5a and c]. While transgenic plants of wheat cultivars stayed healthy and green [Figure $5 b$ and $d$ ]. 

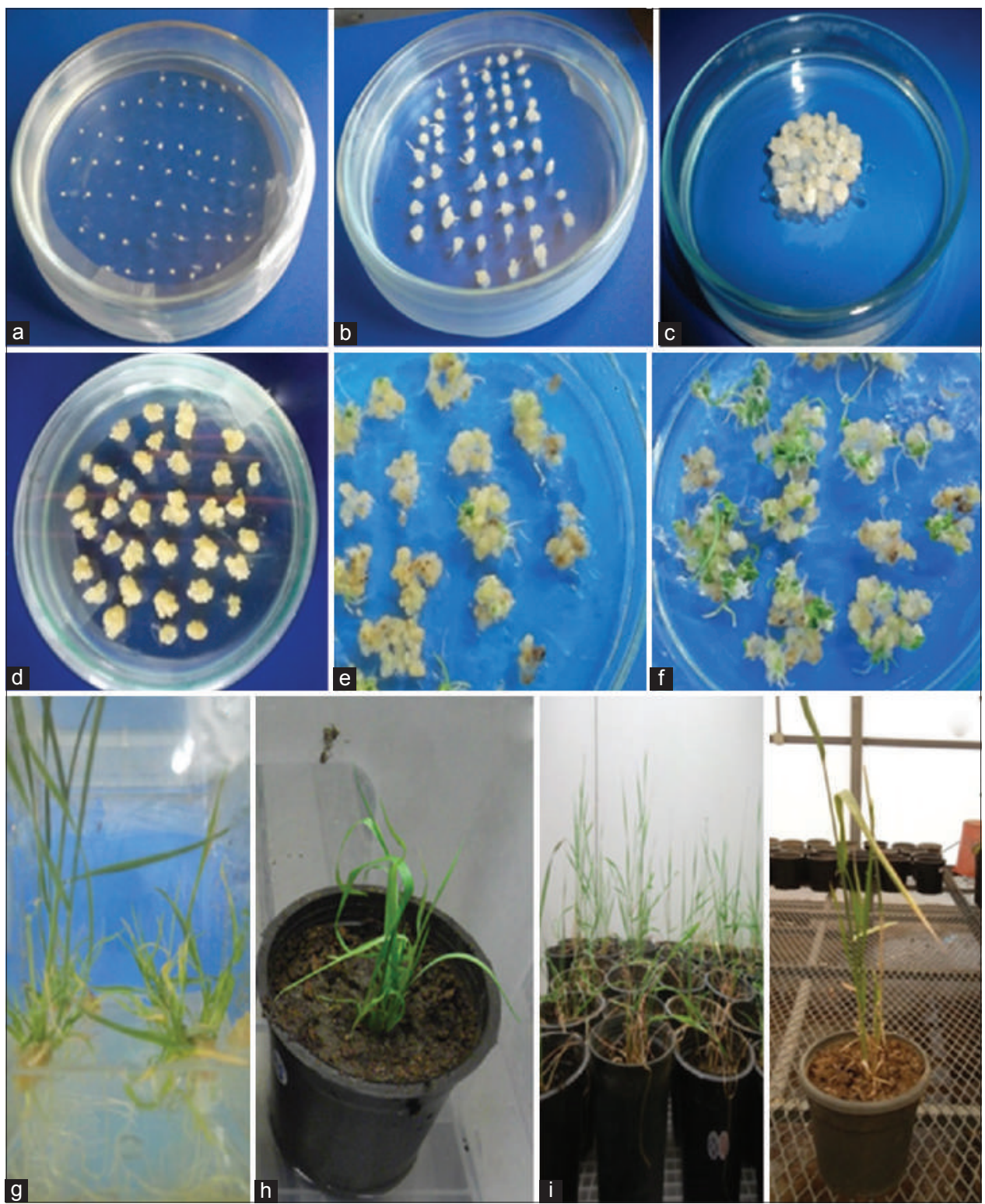

Figure 3: Production stages of transgenic durum wheat cultivar Bani Suef 6 with pAHcht-2 and pAB6 plasmids by particle bombardment. (a) Immature embryos cultured on callus induction medium. (b) Induced calli on callus induction medium. (c) Induced calli on osmotic medium. (d) Bombarded calli on callus induction recovery medium. (e) Calli on selection medium containing $3 \mathrm{mg} / \mathrm{L}$ phosphinothricin. (f) Regeneration of putative transgenic plantlets. (g) Plantlets on rooting medium. (h and i) Acclimation of putative transformed plants.

\subsection{Screening of Transgenic Plants for the Transgenes}

The leaf genomic DNAs extracted from all the independent putative transformants in both bread wheat cultivar (Sids 1) and durum wheat cultivar (cv. Bani Suef 6) and tested by PCR amplification using primers specific to $c h t-2, b a r$, and gus genes.

PCR results revealed products of the expected sizes for all transgenes; $1100 \mathrm{bp}$ for cht-2 gene, $443 \mathrm{bp}$ for bar gene, and $1050 \mathrm{bp}$ for gus gene [Figures 6 and 7].

Transformation frequency for cht-2, bar, and gus genes recorded higher values in case of cv. Sids 1 calculated by $3.96 \%, 5.29 \%$, and $5.02 \%$, respectively, compared to $3.02 \%, 4.67 \%$, and $3.57 \%$, respectively, in durum wheat cultivar Bani Suef 6 .

\subsection{Dot Blot Analysis}

The stable integration of cht-2 gene into the genome of the PCR positive transformants in bread wheat cultivar and durum wheat cultivar was also confirmed by cht-2 Dot blot assay [Figure 8]. Genomic DNA isolated from PCR-positive plants of both wheat cultivars was denatured, neutralized, and then subjected to Dot blotting using the probe for chitinase gene; non-transformed plant was used as negative control. The obtained results are similar to PCR analysis results, 15 transformed plants in the case of $\mathrm{cv}$. Sids 1 and 11 transformed plants in the case of cv. Bani Suef 6 were positive for PCR analysis and Dot blot.

\section{DISCUSSION}

Although wheat represents the major food for wide world, it was the latest of cereals that transformed. Genetic transformation of wheat 

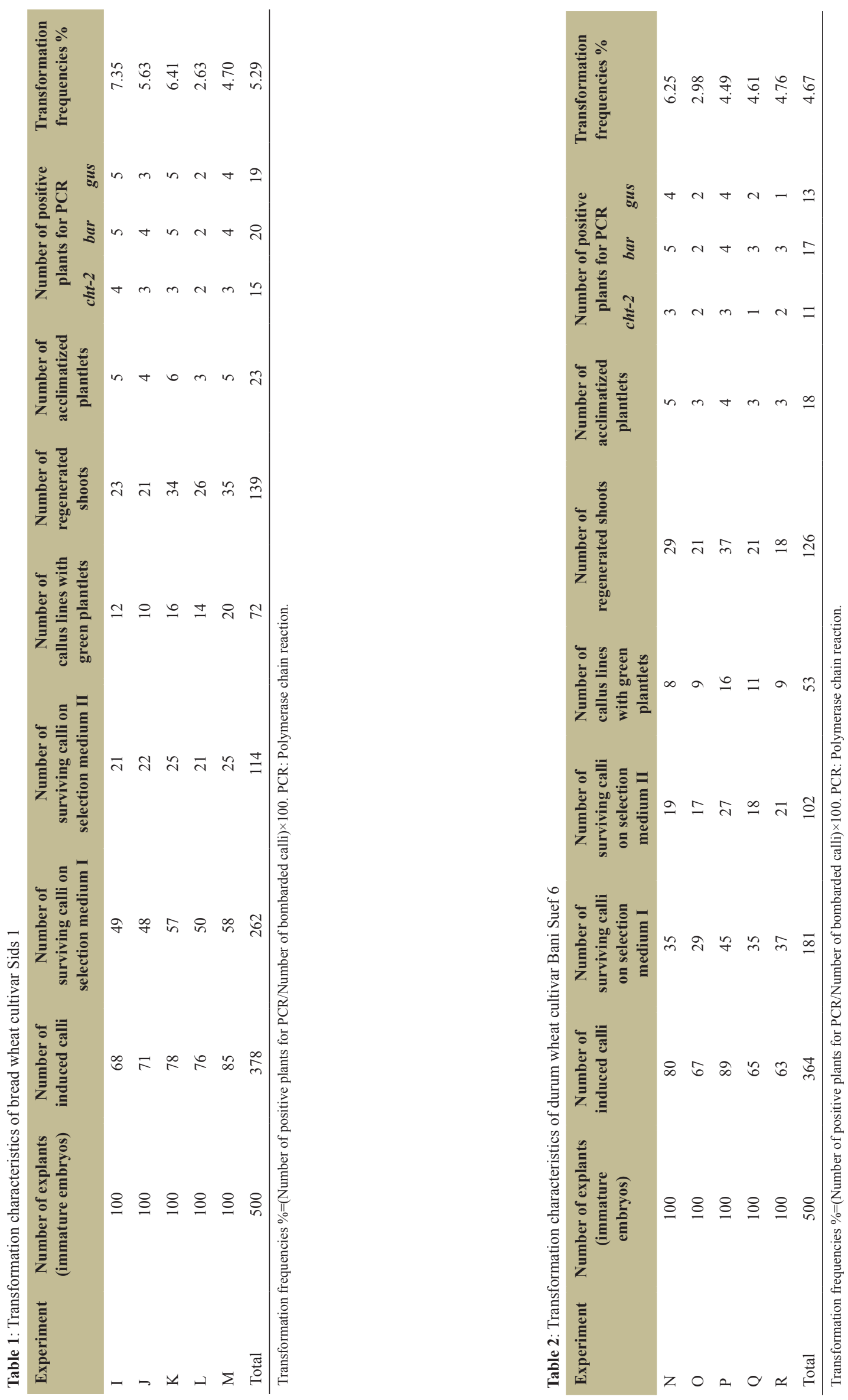


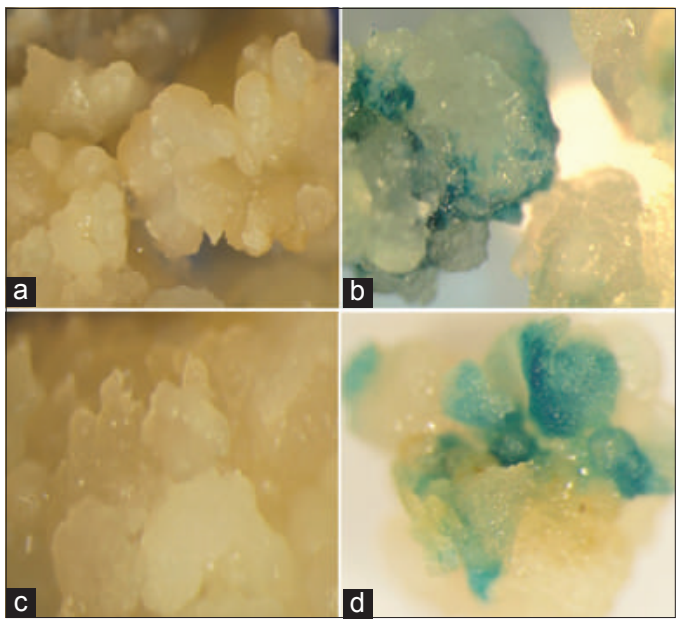

Figure 4: Expression of gus gene in embryogenic callus derived from scutellum tissues of bread wheat plants (cv. Sids 1) and durum wheat (cv. Bani Suef 6) after 48 from bombardment with pAHCht-2 plasmid and pAB6 plasmid. (a) Non-transformed callus; (b) transformed callus of cv. Sids 1 (c) non-transformed callus; and (d) transformed callus of cv. Bani Suef 6

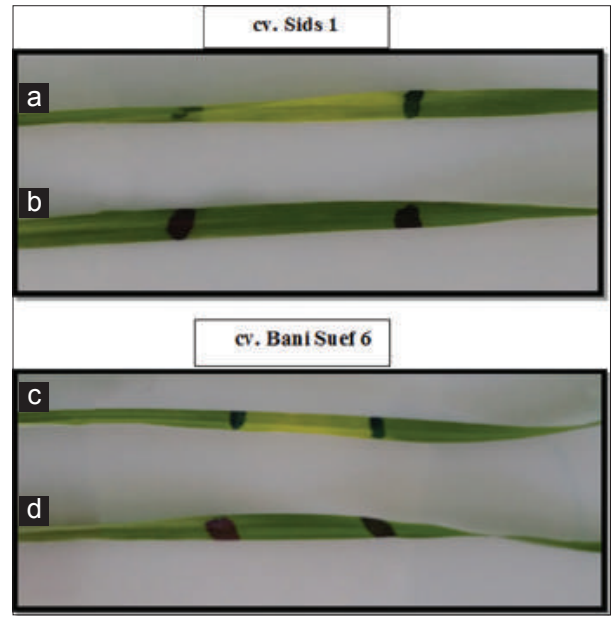

Figure 5: Identification of the herbicide resistance of the leaves of transgenic wheat plants using $0.2 \%$ Liberty herbicide solution. (a and c) Non-transgenic leaves are showing necrosis; ( $b$ and d) transgenic leaves showing resistance to herbicide in both wheat cultivars.

was low in successful because of many technical difficulties such as reduction of transformation frequencies, shortage of suitable explant source (immature embryos), which is not available throughout the year. Vasil et al. [22] reported the first fertile transgenic wheat using immature embryos. There are numerous reports employing immature and mature embryo, embryo derived-calli and scutellar tissue as the explants for transformation by biolistic gun [13,23-29].

In Egypt, bread wheat (T. aestivum L.) and durum wheat ( $T$. turgidum ssp. Durum) are largely cultivated. The grain used for the human alimentation and animal feeds. In this study, rice chitinase gene was introduced into Egyptian wheat to improve pathogen resistance. Two Egyptian wheat cultivars have been used, bread wheat cultivar (Sids 1) and durum wheat cultivar (Bani Suef 6). The chitinase gene has been used for defending crop plants from fungal diseases. The advantages of using chitinases to protect plant are these fungicidal enzymes are part of the plant defense system and
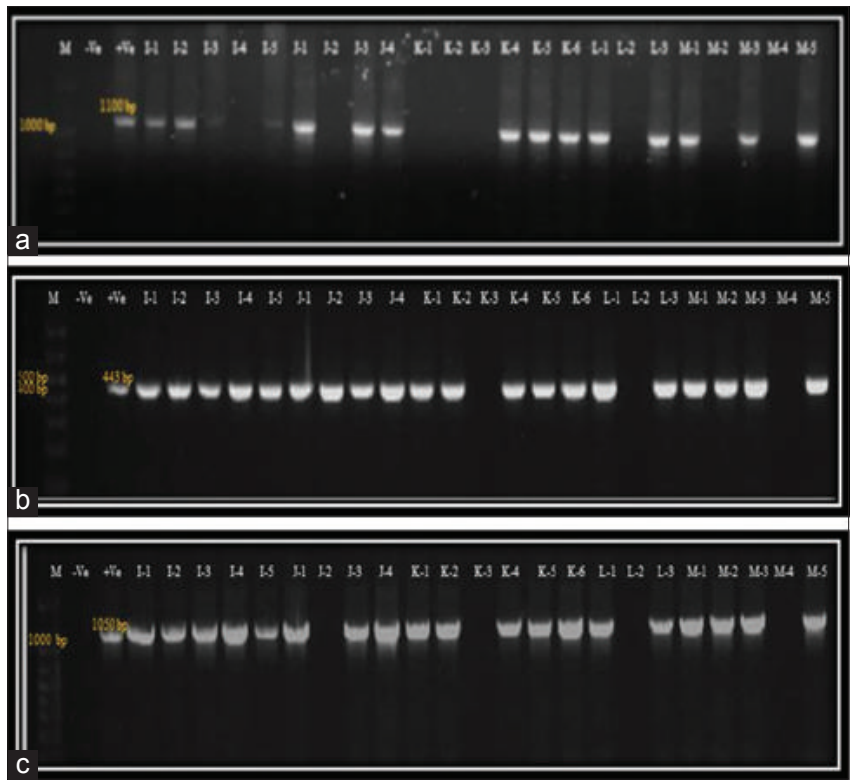

Figure 6: Polymerase chain reaction (PCR) screening analysis of genomic DNA from leaf tissues of $\mathrm{T}_{0}$ transgenic bread wheat plants cv. Sids 1 . Lane (M) is DNA marker (100 bp ladders). (-Ve) genomic DNA from nontransgenic plant as negative control, (+ve) plasmid pAHCht-2 in (a) and plasmid pAB6 in b and c. Lanes I-1- M-5: Genomic DNA from leaf tissues of $23 \mathrm{~T}_{0}$ transgenic plants of cv. Giza 164 was used in PCR reaction. (a) Amplification product of Cht-2 gene (1100 bp). (b) Amplification product of bar gene (443 bp). (c) Amplification product of gus gene (1050 bp).
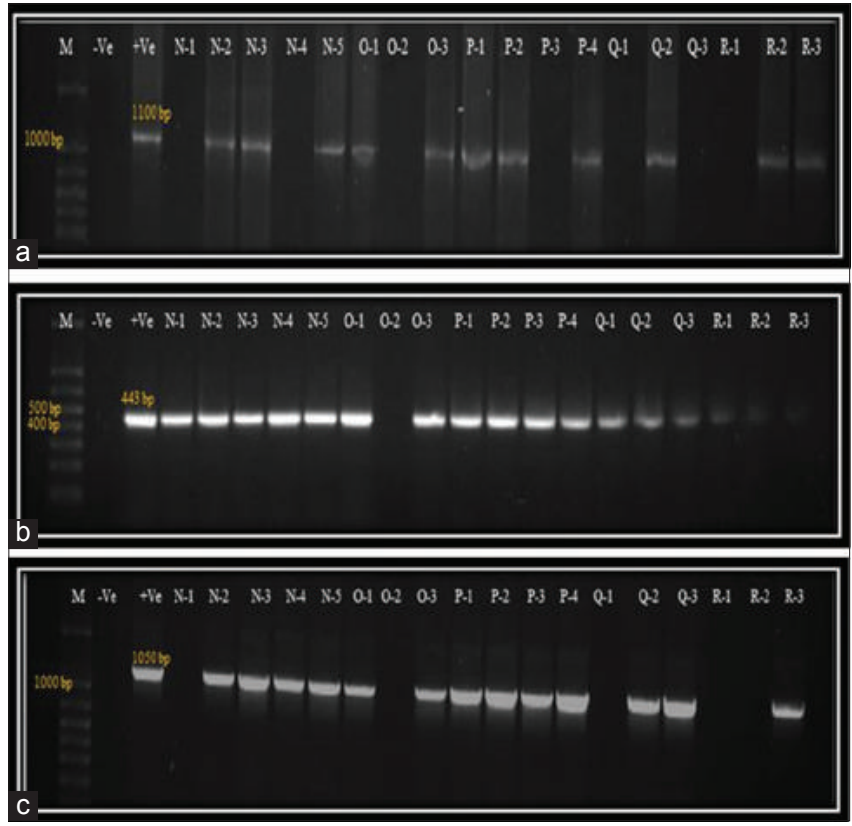

Figure 7: Polymerase chain reaction (PCR) screening analysis of genomic DNA from leaf tissues of $\mathrm{T}_{0}$ transgenic durum wheat plants cv. Bani Suef 6 . Lane (M) is DNA marker (100 bp ladder). (-Ve) Genomic DNA from nontransgenic plant as a negative control, (+Ve) plasmid pAHCht-2 in (a) and plasmid pAB6 in b and c. Lanes N-1- R-3: Genomic DNA from leaf tissues of $18 \mathrm{~T}_{0}$ transgenic plants of cv. Giza 164 was used in PCR reaction. (a)

Amplification product of Cht-2 gene (1100 bp). (b) Amplification product of bar gene (443 bp). (c) Amplification product of gus gene (1050 bp). 


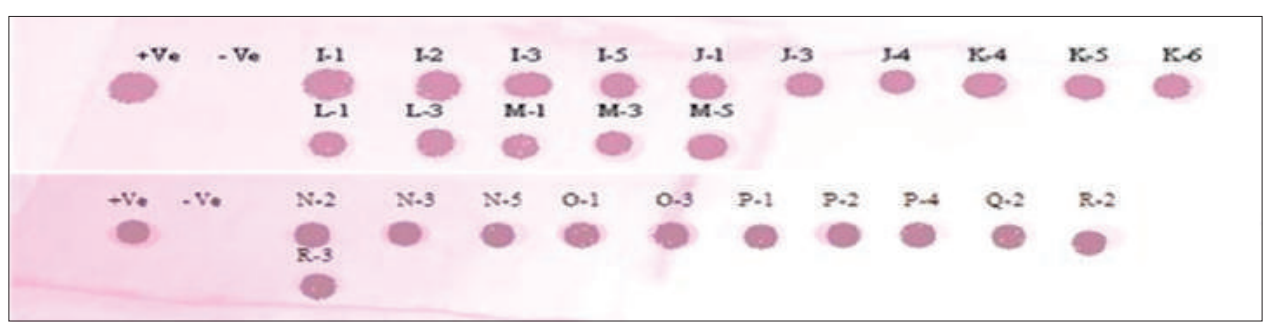

Figure 8: Dot blot analysis of transgenic wheat (a) cv. Sids 1 plants; Dot (+Ve) is pAHCht-2 plasmid (positive control), Dot (-Ve) is non-transformed wheat cv. Sids 1 (negative control), and Dots (I-1- M-5) are the 15 wheat Cht-2 transgenic plants and (b) cv. Bani Suef 6 plants; Dot (+Ve) is pAHCht-2 plasmid (positive control), Dot (-Ve) is non-transformed wheat cv. Bani Suef 6 (negative control) and Dots (N-2- R-3) are the 11 wheat Cht-2 transgenic plants.

not harmful to plants, as the substrate chitin is not found in plants. It has been proposed that overexpression of a chitinase transgene protein may function to provide fungal pathogen resistance on both direct and indirect levels. On the direct level, it degrades chitin of growing hyphae, whereas on the indirect level it results in the release of chitin oligomers which can act as elicitors of plant defense mechanisms [30,31].

In the present study, the bread wheat cultivar (Sids 1) recorded higher regeneration frequency reached to $63.15 \%$ compared with durum wheat cultivar (Bani Suef 6) which recorded only $51.96 \%$ as shown in Tables 1 and 2. The use of TDZ resulted in higher regeneration frequencies in wheat plants as reported by several authors [32-34]. In monocotyledons species, several authors reported that TDZ induces multiple shoot formation. In this respect, Shan et al. [32] demonstrated that the regeneration percentage of barley and wheat was higher on medium containing TDZ than other plant growth regulators. This indicates TDZ is an efficient regulator for in vitro regeneration of barley and wheat.

The transformation frequency in wheat plants in literature was low and depended significantly on the genotype. In this respect, transformation frequencies in previous reports were $2.4 \%$ by Burdon et al. [35]; $0.6-3.1 \%$ by Tosi et al. [36]; $1.4-3 \%$ by Mackintosh et al. [37]; and 1.8-2.7 by Fahmy et al. [29]. In the present work, transformation frequency was $5.29 \%$ for cv. Sids 1 and $4.67 \%$ for cv. Bani Suef 6 [Tables 1 and 2]. Several studies have been reported that the variability of transformation frequencies was more due to the genotypic and physiological status of the donor plants that due to the efficiency of the biolistic procedure [38].

PCR method is used to confirm integration of the transgenes in putative of wheat cultivars as shown in Figures 6 and 7. In this study, cht-2 gene introduced into two Egyptian wheat cultivars by gene gun bombardment, and conducted the fast DNA molecular identification by dot blot hybridization and PCR. These methods efficiently and conveniently identify transgenic plants, but it was still necessary to conduct further identification by Southern blotting hybridization to evaluate the performance of transformed exogenous genes.

To confirm the presence of cht-2 in the putative plants $\mathrm{T}_{0}$, all the independent putative transforming wheat cultivars were analyzed by PCR amplification using primers specific to $c h t-2$ gene. PCR analysis amplified the expected size for cht-2 (1100 pb). As shown in Tables 1 and $265 \%$ and $61 \%$ of cv. Sids 1 and cv. Bani Suef 6, respectively, exhibited the expected size. DNA Dot blot was performed, and positive signal after hybridization of the genomic DNA with the probe was detected in putative plants of three wheat cultivars as shown in Figure 8. This method provides advantages of rapid, easy, and convenient analysis $[39,40]$.

In addition, the integration of marker genes (gus and bar) was confirmed in the genome of the putative plants of three wheat cultivars by PCR technique. PCR results revealed products of the expected sizes, $1050 \mathrm{bp}$ for gus gene and $444 \mathrm{bp}$ for bar gene as shown in Figures 6 and 7. Expression of marker genes was examined histochemically for gus activity and by leaf painting assay for bar.

Plants that survived after selection, but revealed negative PCR for the presence of transgene (bar) were considered escapes. The number of 139 and 126 plantlets survived after the two selection stages for cv. Sids 1 and Bani Suef 6, respectively. Only 23 and 18 plants grow to maturity, and 23 and 17 were PCR positive for the selection marker gene bar for cv. Sids 1 and Bani Suef 6, respectively. This study recorded $14.38 \%$ and $13.49 \%$ escapes for cv. Sids 1 and Bani Suef 6, respectively. Wheat transformation suffers high escape frequencies (50-95\%) as reported by several workers [23,29,41-44].

\section{CONCLUSION}

We successfully transferred rice chitinase (cht 2) gene, and bar gene into an immature embryo-derived calli of two Egyptian wheat cultivars by biolistic device to enhance resistance against pathogens and herbicide. This genetic engineering approach may be improved wheat quality and yield. Transformation frequencies were higher in bread wheat cultivar than in durum wheat cultivar. At the moment, these data are only valid for the wheat cultivars used. If nothing more, they indicate that it seems advantageous in the genetic transformation to carefully choose the cultivars with best transformation frequency.

\section{ACKNOWLEDGMENTS}

The authors thank appreciably Prof. Dr. S. Muthukishnan (Department of Biochemistry, Kansas State University, Kansas, USA) for generously providing rice chitinase gene.

\section{REFERENCES}

1. Breiman A, Graur D. Wheat evaluation. Israel J Plant Sci 1995;43:58-95.

2. Bicar EH, Woodman-Clikeman W, Sangtong V, Peterson JM, Yang SS, Lee $\mathrm{M}$, et al. Transgenic maize endosperm containing a milk protein has improved amino acid balance. Transgenic Res 2008;17:59-71.

3. Schlumbaum A, Mauch F, Vogeli U, Boller T. Plant chitinases are potent inhibitors of fungal growth. National 1986;324:365-7.

4. Leah R, Tommerup H, Svendsen I, Mundy J. Biochemical and 
molecular characterization of three barley seed proteins with antifungal properties. J Biol Chem 1991;266:1564-73.

5. Velazhahan R, Samiyappan R, Vidhyasekaran P. Purification of an elicitor-inducible antifungal chitinase from suspension cultured rice cells. Phytoparasitica 2000;28:131-9.

6. Wani SH. Inducing fungus resistance into plants through biotechnology. Not Sci Biol 2010;2:14-21.

7. Hamid R, Khan MA, Ahmad MM, Abdin MZ, Musarrat J, Javed A. Chitinase: An update. J Pharm Biol Sci 2013;5:21-9.

8. Tabei Y, Kitade S, Nishizawa Y, Kikuchi N, Kayano T, Hibi T, et al. Transgenic cucumber plants harboring a rice chitinase gene exhibit enhanced resistance to gray mold (Botrytis cinerea). Plant Cell Rep 1998;17:159-64.

9. Chen WP, Gu W, Liang GH, Muthukrishnan H, Chen PD, Liu DJ, et al. Introduction and constitutive expression of a rice chitinase gene in bread wheat using biolistic bombardment and the bar gene as a selectable marker. Theor App Genet 1998;97:1296-306.

10. Datta K, Tu J, Oliva N, Ona II, Velazhahan R, Mew TW, et al. Enhanced resistance to sheath blight by constitutive expression of infection-related rice chitinase in transgenic elite Indica rice cultivars. Plant Sci 2001;160:405-14.

11. Jabeen N, Chaudhary Z, Gulfraz M, Rashid H, Mirza B. Expression of rice chitinase gene in genetically engineered tomato confers enhanced resistance to Fusarium wilt and early blight. Plant Pathol J 2015;31:252-8.

12. Fahmy AH, El-Shihy O, El-Shafey YH, Modkour MA. Genetic transformation of Egyptian wheat cultivar (Triticum aestivum L.) via biolistic bombardment using different constructs. Am Eurasian J Agric Environ Sci 2006;1:58-69.

13. Murashige T, Skoog F. A revised medium for rapid growth and bioassays with tobacco tissue cultures. Physiol Plant 1962;15:473-97.

14. Weeks JT, Anderson OD, Blechl AE. Rapid production of multiple independent lines of fertile transgenic wheat (Triticum aestivum). Plant Physiol 1993;102:1077-84.

15. El-Mangoury KA, Abdrabou RT, Yasien M, Fahmy AH. Optimization of a transformation system for three Egyptian wheat cultivars using immature embryo derived callus via micro-projectile bombardment. Arab J Biotech 2006;9:175-88.

16. Ausubel FM, Brent R, Kimgston RE, Moore D, Serdman JG, Smith A, et al. Current Protocols in Molecular Biology. New York, USA: Green Publishing Associates and Wiley Inter-science; 1987. p. 1-4.

17. Tu Z, He G, Li KX, Chen MJ, Chang J, Chen L, et al. An improved system for competent cell preparation and high efficiency plasmid transformation using different Escherichia coli strains. Electron J Biotech 2005;8:113-20.

18. Sanford JC, Smith FD, Russell JA. Optimizing the biolistic process for different biological application. Methods Enzymol 1993;217:483-509.

19. Jefferson RA, Kavanagh TA, Bevan MW. GUS fusions: $\beta$-glucuronidase as a sensitive and versatile gene fusion marker in higher plants. EMBO J 1987;6:3901-7.

20. Cho MJ, Jiang W, Lemaux PO. Transformation of recalcitrant barley cultivars through improvement of regenerability and decreased albinism. Plant Sci 1998;138:229-44.

21. Sambrook J, Fritsch EF, Maniatis T. Molecular Cloning: A Laboratory Manual. $2^{\text {nd }}$ ed. Cold Spring Harboor, NY: Cold Spring Harbor Laboratory Press; 1989.

22. Vasil V, Castillo AM, Fromm ME, Vasil IK. Herbicide resistant fertile transgenic wheat plants obtained by micro projectile bombardment of re-generable embryo genic callus. Nat Biotech 1992;10:667-74.

23. Nehra NS, Chibbar RN, Leung N, Caswell K, Mallard C, Steinhauer L, et al. Self-fertile transgenic wheat plants regenerated from isolated scutellar tissues following micro projectile bombardment with two distinct gene constructs. Plant J 1994;5:285-97.
24. Witrzens B, Brettell RI, Murray ER, McElroy D, Li Z, Dennis ES. Comparison of three selectable marker genes for transformation of wheat by micro projectile bombardment. Aust J Plant Physiol 1998;25:39-44.

25. Zhang L, Rybczynski JJ, Langenberg WG, Mitra A, French R. An efficient wheat transformation procedure: Transformed calli with long-term morph genic potential for plant regeneration. Plant Cell Rep 2000;19:241-50.

26. Patnaik D, Khurana P. Genetic transformation of Indian bread (T. aestivum) and pasta (T. Durum) wheat by particle bombardment of mature embryo-derived calli. BMC Plant Biol 2003;3:5.

27. Jia H, Yu J, Yi D, Cheng Y, Xu W, Zhang L, et al. Chromosomal intervals responsible for tissue culture response of wheat immature embryos. Plant Cell Tissue Organ Cult 2009;97:159-65.

28. He Y, Jones HD, Chen S, Chen XM, Wang DW, Li KX, et al. Agrobacterium-mediated transformation of durum wheat (Triticum turgidum L. Var. Durum cv stewart) with improved efficiency. J Exp Bot 2010;61:1567-81.

29. Fahmy AH, El Mangoury K, El-Wafa WA, Barakat HM, El-Khodary S, Muthukrishnan S. Genetic transformation of Egyptian wheat (Triticum aestivum L.) with chitinase gene via micro projectile bombardment. Egyptian J Genet Cyto 2013;42:233-45.

30. Collinge DB, Kragh KM, Mikkelsen JD, Nielsen KK, Rasmussen U, Vad K, et al. Plant chitinases. Plant J 1993;3:31-40.

31. Takahashi W, Fujimori M, Miura Y, Komatsu T, Nishizawa Y, Hibi T, et al. Increased resistance to crown rust disease in transgenic Italian ryegrass (Lolium multiflorum lam.) expressing the rice chitinase gene. Plant Cell Rep 2005;23:811-8.

32. Shan XY, Li DS, Qu RD. Thidiazuron promotes in vitro regeneration of wheat and barley. In Vitro Cell Dev Biol Plant 2006;36:207-10.

33. Ganeshan S, Chodaparambil SV, Ga MB, Fowler DB, Hucl P, Rossnagel PG, et al. In vitro regeneration of cereals based on multiple shoot induction from mature embryos in response to thidiazuron. Plant Cell Tissue Organ Cult 2006;85:63-73.

34. Gill AK, Gosal SS, Salu SK. Differential cultural responses of wheat (Triticum aestivum L.) with different explants. J Cell Tissue Res 2014;14:4351-6.

35. Burdon V, Wickhan A, Lonsdale D, Harwood W. Additional introns inserted within the luciferase gene stabilize transgene expression in wheat. Plant Sci 2004;167:1143-9.

36. Tosi P, D'Ovidio R, Napier JA, Bekes PR, Expression of epitopetagged LMW glutenin subunits in starchy endosperm of transgenic wheat and their incorporation into glutenin polymers. Theor Appl Genet 2004;108:468-76.

37. Machintosh CK, Lewis J, Radmer LE, Shin S, Heinen SJ, Smith LA, et al. Overexpression of defense response genes in transgenic wheat enhances resistance to Fusarium head blight. Plant Cell Rep 2007;26:479-88.

38. Miroshnichenko DM, Poroshin GM, Dolgov SV. Genetic transformation of wheat using mature seed tissues. Appl Biochem Microbiol 2011;47:767-75.

39. Brown T. Dot and slot blotting of DNA. In: Current Protocols in Molecular Biology. Hoboken, NJ, USA: John Wiley \& Sons; 2001.

40. Haddadi F, Aziz MA, Abdullah SN, Tan SG, Kamaladini H. An efficient Agrobacterium mediated transformation of strawberry cv. Camarosa by a dual plasmid system. Molecules 2015;20:3647-66.

41. Becker D, Brettschneider R, Lörz H. Fertile transgenic wheat from micro projectile bombardment of scutellar tissue. Plant J 1994;5:299-307.

42. Bieri S, Potrykus I, Fütterer I. Expression of active barley seed ribosome-inactivating protein in transgenic wheat. Theor App Genet 2000;100:755-63.

43. Roy-Barman S, Sautter C, Chattoo BB. Expression of the lipid transfer protein Ace-AMP1 in transgenic wheat enhances antifungal 
activity and defense responses. Trans Res 2006;5:435-46.

44. Kasirajan L, Boomiraj K, Bansal KC. Optimization of genetic transformation protocol mediated by biolistic method in some elite genotypes of wheat (Triticum aestivum L.). Afr J Biotech 2013;12:531-8.
How to cite this article:

Fahmy AH, Hassanein RA, Hashem HA, Ibrahim AS, El Shihy OM,

Qaid EA. Developing of transgenic wheat cultivars for improved disease

resistance. J App Biol Biotech. 2018;6(2):31-40.

DOI: $10.7324 / J A B B .2018 .60206$ 